\title{
The Neoliberal Food Regime: Neoregulation and the New Division of Labor in North America
}

\author{
Gabriela Pechlaner \\ Department of Social, Cultural and Media Studies, University of the Fraser Valley

\section{Gerardo Otero} \\ Department of Sociology and Anthropology, Simon Fraser University
}

\begin{abstract}
We undertake a comparative investigation of how neoliberal restructuring characterizes the third food regime in the three North American countries. By contrasting the experience of the two developed countries of the United States and Canada with that of the developing country of Mexico, we shine some empirical light on the differential impact of neoliberal regulatory restructuring on the division of labor in agriculture within the North American Free Trade Agreement region. In particular, we investigate these countries' agricultural production markets, trade, and food vulnerability-with an emphasis on Mexico-as analytical points for comparing and contrasting their experience with this neoliberal restructuring. We start with a synthesis of food-regime theory and outline the key features of what we call the "neoliberal food regime." We then discuss our case-study countries in terms of food vulnerability and resistance in Mexico, their differential relationships to trade liberalization, and what these trends might mean for the evolution of the neoliberal food regime. We conclude that, while dominant trends are ominous, there is room for an alternative trajectory and consequent reshaping of the emerging regime: sufficient bottom-up social resistance, primarily at the level of the nation-state, may yet produce an alternative trajectory.
\end{abstract}

In a synthetic article about agrarian studies at the end of the twentieth century, Frederick Buttel (2001) observed that, with the rise of globalization, the fields of sociology of agriculture and food and the sociology of development were converging. Yet he lamented that individual sociologists of agriculture remained specialists in developed-country or southern agrifood systems: "Little groundwork has been laid for a sociology of agriculture that addresses simultaneously the agrarian change issues of both North and South" (Buttel 2001:177). In this article, we attempt to contribute to bridging this gap, at least for the region covering the three countries of the North American Free Trade Agreement (NAFTA): Canada, the United States, and Mexico.

Given agriculture and food's special importance for subsistence and its importance for international trade, a key factor in its globalization is regulation, most specifically, national and international regulation for trade liberalization. It is a contentious issue given that food cannot be separated from important social considerations, such as food vulnerability, especially in developing countries, where subsistence farming still 
plays a significant role. Consequently, agriculture's role in trade liberalization has been a central theme in international regulatory negotiations. On one side, the World Trade Organization (WTO) has been pushing for liberalization, but on the other peasant social movements defend the idea of food sovereignty (Desmarais 2007).

Globalization is thus most convincingly portrayed not as some external juggernaut of corporate-friendly international regulation that washes over helpless nations, but as an ideologically driven political project (Harris 2002; McBride and Shields 1997; McMichael 1996, 2004a; Otero 1996; Urmetzer 2005). Hence we refer to it as "neoliberal globalism," to highlight the ideological underpinning of what we call neoregulation. Because neoliberal globalism is an ideology, which happens to have been dominant since the 1980s, it can also be contested and defeated, including the policies emanating from it. Rather than using the common notion of "deregulation," which implies that state intervention withers away and states in general lose power, we propose the term "neoregulation." Following Karl Polanyi's (1944) theorization of the previous wave of liberalization, neoliberal globalism also depends centrally on the state and its attempt to impose the market as a self-regulating mechanism. The state, while changed in significant ways, continues to play a central role in neoliberal times (Hay, Lister, and Marsh 2006; Otero 2004a). Nonetheless, significant inequality and power imbalances between different nation-states affect their specific modes of incorporation into the project of neoliberal globalism. Nation-states with the greatest international clout will be most influential in setting up the global regulatory regime, around which less powerful nation-states will need to strategize and adapt (Ó Riain 2000; Weiss 1997). As Philip McMichael put it, "the world market is a political construct in which exchanges between unequal societies and/or incommensurable cultures privilege powerful states and institutions" (McMichael 2004a:138).

In line with the neoliberal-globalization dynamics outlined above, we draw on the historical trajectory of agriculture's internationalization (Sanderson 1986), as outlined in the food-regime (FR) perspective articulated by Harriet Friedmann and Philip McMichael (Friedmann 1992, 1993, 1995, 2000; Friedmann and McMichael 1989; McMichael 1992, 2004b). In Frederick Buttel's view, “'regime-type' work has proven to be one of the most durable perspectives in agrarian studies since the late 1980s, in large part because it is synthetic and nuanced." The world-system logic of this perspective offers a view of the food regime as not merely an economic phenomenon, but also a political one: "it reflects periodic shifts in hegemonic regimes which are anchored in the politics of how commodity chains and production systems come to be 
constructed and coordinated over borders and boundaries" (Buttel 2001:173). Friedmann and McMichael identified two past food regimes, and suggested that we were in transition to a third. The characteristics of this third regime were still unfolding, but it was most frequently articulated as a corporate-friendly international regulatory regime that some consider crippling to state autonomy. Predictions that the internationalization of the regulatory regime and the state-initiated institutionalization of corporate rights will be key features of the third food regime have proven durable. Therefore, contrary to the optimism of free-trade proponents, the neoliberal regime is primed to extend and entrench existing inequalities between nation-states.

Yet theorization about the state-facilitated reorganization of global agriculture into a third food regime is lagging. Outside of a general or macro focus on international regulations and influences, FR scholars have had some difficulty articulating its current-rather than historical-influences (Le Heron and Roche 1995; Moran et al. 1996; Pritchard 1998). While later works by Friedmann and McMichael (Friedmann 2005; McMichael 2004b) cast more attention to the dynamics that might contribute to the shaping of what McMichael calls the corporate food regime, this work remains focused on global transformations, and is more macro oriented and theoretical rather than empirical. Farshad Araghi (2003) made an important methodological contribution to the perspective, arguing for a labor-oriented approach, rather than one focused on capital's development. Later contributions by McMichael have adopted this perspective, based on the labor theory of value, but remain short on empirical backing.

Further, while most globalization and FR literature tends to downplay or ignore local agency-for example, through social movements or popular resistance-in mediating or perhaps even reshaping the globalization and global-value dynamic, a growing body of scholarship indicates that such local forces can, in fact, temper its implementation (see, e.g., Constance et al. 2003; Novek 2003; Wells 1997). Constance et al., among others, argue that the decoupling of community benefit from economic development according to globalization dynamics creates significant community resistance. We believe this dynamic is vastly exacerbated when the issue relates not just to economic benefit but to survival itself, such as in the case of food vulnerability. In order to close the conceptual gaps in the FR perspective, empirical research on neoregulation and its resistances needs to be based at the local level, while keeping the global framework in sight. At the local level, we can see the impacts of neoregulation and social actors' responses to it, often in opposition to what their governments negotiate on the global stage. 
We hypothesize that the globalization of agriculture and food will be tempered not only by the differential interests and abilities of individual nation-states but also by the resistances to neoregulation that arise within them. It is plausible that those nations with the highest level of adoption of neoliberal globalism that are also subject to food vulnerability are the most likely to breed resistances that will prevent its successful implementation. We offer an empirical analysis of how neoregulation has impacted food vulnerability and the division of labor in the three countries of NAFTA: specifically, by contrasting the experience of the two developed countries of the United States and Canada-which albeit have different degrees of international clout-as a backdrop to the experience of the developing country of Mexico. As Mexico is the only NAFTA country with food vulnerability, we emphasize its experience in order to assess the differential impact of the neoliberal food regime and its consequent level of popular resistance.

The first section provides a synthesis of the FR perspective and outlines the key features of the neoliberal food regime. Given that corporations will be around as long as capitalism is, we prefer this label to that of a "corporate" food regime, which is too generic. This distinction makes it clear that corporations, like neoregulation, operate under the impetus of the ideology of neoliberal globalism, which can change with a different configuration of power relations in society. In the second section, we compare the three countries, emphasizing Mexico's experience. From the results, we draw conclusions about their differential relationships to trade liberalization, and what the unsteady incorporation of Mexico might suggest for the evolution of the neoliberal food regime. We argue that, while dominant trends are ominous, there is room for an alternative trajectory and consequent reshaping of the neoliberal food regime.

\section{The Food-Regime Perspective}

Harriet Friedmann and Philip McMichael (1989) have identified two distinct historical food regimes. They designated the first as the "SettlerColonial" regime, and it spanned the period between 1870 and 1914, a period of transition from colonialism to settler states presided over by British hegemony and "extensive" accumulation strategies. The metropole-settler state relationship that evolved during this period, with settler states supplying cheap provisions for the industrializing metropolis, created the potential for an international division of labor in agriculture. As a result, this period saw nationally organized agriculture become a distinct capitalist sector, with production based on comparative advan- 
tage (1989:102). While agricultural products were traded internationally, they were still nationally organized and constrained.

The second food regime was post-World War II, spanning the period between 1945 and 1973. A period of U.S. hegemony, its agricultural policies, designed to support its farm sector, led to a "Surplus" regime. The United States drove agriculture's exemption from international free-trade rules and helped designate it a nationally regulated sector, supported through trade restrictions and farm supports (Friedmann 1993). The issue of subsequent grain surpluses was addressed through food aid to developing countries, ultimately creating southern dependency on cheap-food imports (Burbach and Flynn 1980; Otero and Pechlaner 2008). At the same time, the integration and internationalization of agrifood capital through trade liberalization and advances in preservation technologies resulted in the rise of agrifood complexes, specifically the wheat, livestock, and durable foods complexes (Friedmann 1992). Consequently, the end of this regime saw corporatedominated international integration of production and consumption relations around agriculture and food. These relations were based in particular geopolitical power blocks-most notably, northern power and southern dependency. The instability in world markets in the 1970s facilitated the collapse of this regime.

Articulating the shapes of the past two regimes demonstrates how the features of the first regime became the precondition for the second. Similarly, the surplus regime subsequently set the stage for a third food regime. As noted by Friedmann (2005), a period of crisis follows regime collapse, during which time its resolution is open to various influences. Such openness has also led to differing characterizations of the third regime-for example, McMichael's "Corporate Food Regime," Friedmann's "Corporate-Environmental Food Regime," and our "Neoliberal Food Regime." Even so, a number of consistent features have already been identified. As articulated by McMichael, the basis of the third regime is "centred on the political elimination of barriers to capital in social and natural relations" (2004b:4). In sum, it is characterized by even deeper integration of transnational agrifood capital, where global sourcing is the norm, and the national regulation of agriculture is challenged both by corporate-economic strategies and by further international-trade liberalization pressures.

Viewed globally, the "undermining of local farming and informal provisioning ... and displacing independent producers via expanding agro-exporting" are inherent parts of this process, as these "extant systems of provisioning" must be interrupted or eliminated in order to convert them "into supply chains for the corporate, 'food from nowhere' 
regime" (McMichael 2004b:11). It is important to note that this regime often involves the production of high-value agricultural goods in developing countries for rich consumers in developed countries. The fresh fruit and vegetable sector is an important example of such production (Barndt 2004, 2008; Nagatada 2006; Pritchard and Burch 2003; Stanford 2004). Further, export-oriented agriculture from new agricultural countries and import complexes arising from developing country food dependence have been identified as central features of "contemporary global food politics" (Fold and Pritchard 2005:5). While the contours of NorthSouth relations are already evident from the above discussion, far more empirical work needs to be done on this relationship, and how it can help characterize the overall shaping of the regime.

Both Friedmann (2005) and McMichael (2004b) have partially responded to critiques over the FR perspective's weakness in accounting for national differentiation and in its predictive ability through separate articles articulating their vision of the dynamics that will play into its resolution. While their focus is broad in scope and each has a different emphasis, both scholars acknowledge the interplay between neoliberal regulatory restructuring and social movements. McMichael (2004b) argues that the WTO-style transformation to a liberalized "world agriculture" (premised on comparative advantage and market exchange as the basis of food security) is countered by a competing vision of food sovereignty that protects small-holder agricultures and those with little market recourse to food (encapsulated in the international vision of Via Campesina [Desmarais 2007]). Friedmann (2005) focuses on the cumulative impact of "green" pressures brought by consumers and social-movement actors, to argue that two systems are emerging and are in tension in the formation of the third regime: one comprising fresh, relatively unprocessed food, often with specific social criteria and overseen by private standards, for rich consumers; and the other producing highly engineered and "denatured" edible commodities, overseen by public and (increasingly lowered) transnational regulations, for poor consumers.

Whether the pressure from these social-movement or resistance groups facilitates a shift in emphasis from "food security" to "food sovereignty" or resolves into a bifurcated "rich" and "poor" double FR (or some such combination) will be the result of myriad influences. For our part, we argue that the most significant influence is likely to be the cumulative impact of neoregulation on food vulnerability and its resistances at the level of the nation-state. While McMichael (2004b) similarly sees the main contemporary dialectic as one between empire and food sovereignty, his view of resistance places it on a transnational level, following the Via Campesina instance. In contrast, we consider that the 
nation-state continues to be the central sphere of struggle (Bartra and Otero 2005; Otero 2004a), even if international solidarity will always be important. Again following Polanyi, we argue that neoliberal globalism in general, and food vulnerability in particular, are sparking a societal protective movement in middle or semiperipheral nations such as Mexico, which have the ability to be self-sufficient in food production. In these cases, at least, social mobilization could yet redirect the neoliberal development model into a popular-democratic route.

Lastly, as Pechlaner and Otero have argued (2008), note that the key technology driving capital accumulation in the neoliberal food regime is genetic engineering (GE). Given the growing centrality of this knowledge-intensive technology, those nations that lag behind in its development will likely face a far greater negative impact, aggravated by the strong intellectual protections that prevail under the neoliberal food regime (Mascarenhas and Busch 2006; Otero 2008; Pechlaner 2007). Whether developing countries are affected by direct implementation of transgenic crops, leading to greater technological dependency, or by indirect competition from the importation of GE crops from developed nations, they are the most likely to be negatively affected (Otero and Pechlaner 2009). One of the chief roles of neoregulation has been to further entrench biotechnology as the driving technological form in the neoliberal food regime, as we will discuss next.

\section{Supranational Neoregulation and Responses in NAFTA Countries}

NAFTA was the state response from the three member countries to trade liberalization trends on a regional basis (Clarkson 2008). The goals of NAFTA conform to the familiar trade-liberalization mantra of reducing trade barriers, expanding markets, and facilitating economic stability. They are thus consistent with global trade-liberalization trends. The NAFTA countries have also all been members of the WTO, the key suprastate organization promoting free trade internationally since its inception in 1994. With 153 members as of July 2008, the WTO sets the stage for international trade, including trade in agrifood.

The United States and Canada were founding members of the WTO's predecessor, the General Agreement on Tariffs and Trade (GATT) in 1948. Mexico joined GATT in 1986, marking its government's decision to insert the nation in the neoliberal globalization process. Neoliberal globalism was not merely imposed by suprastate organizations like the International Monetary Fund or the World Bank but embraced by important sectors of Mexico's ruling class (Valdéz Ugalde 1996) and its technocrats in the political class (Babb 2001; Centeno 1994; Morton 
2003). The issue of trade liberalization in agriculture has nonetheless proven to be highly contentious, particularly over the different positions of developing versus developed countries, given that the most protectionist countries are clearly developed ones: the United States, those in the European Union, and Japan.

While GATT contained some provisions for agriculture, it was in the Uruguay round of negotiations (1987-93), and its ultimate conversion into the WTO, that the "first multilateral agreement dedicated to the sector" was created (World Trade Organization [WTO] n.d.a). The WTO also acknowledged the need to continue the reform process, with new negotiations to follow soon after the first years of implementation. The resulting "Agreement on Agriculture" has three "pillars" to reforming trade and neoregulating the sector: market access, export competition, and domestic support. These three pillars had different phase-in periods for countries with different levels of development, with the overall purpose being to overcome the market-distorting national policies in the sector.

Further agricultural liberalization was to be pursued during the ninth round of WTO negotiations in Doha in 2001. This was considered the "development round," with the Doha ministerial declaration giving "developing country issues a high priority in the negotiations" (USDA, Economic Research Service 2001). An important issue for developing countries is the nontrade concerns associated with agriculture and food: food security, poverty alleviation, rural development, and migration resulting from the failure of small-scale farming. Negotiations continued through a fifth ministerial conference in Cancun in 2003, but the meeting was "soured by discord on agricultural issues" (WTO, n.d.b). A sixth ministerial meeting in Hong Kong in 2005 reportedly had some success, and it established a new timetable for negotiations to be completed in 2006 (WTO n.d.b). By July 2006, however, negotiations were suspended and openly said to have "failed."

The explanation for the cause of the failure depends on where one stands in relation to the issue of whether developing countries require special provisions or whether the overriding goal is to create uniform rules for all. In a statement following the suspension of negotiations, the Indian minister for commerce and industry, Kamal Nath, argued that its cause was a result of those who wanted to turn the round "into a market access Round for subsidized agricultural products." In contrast, the minister argued, there is a need for livelihood security, and if such issues were not considered in the Doha round on development, when would they be? (Nath 2006). India is not alone in this perspective. A group of developing nations, including Mexico, formed in 2003 in opposition to what they 
considered the protectionist tendencies of developed countries under the auspices of the WTO "free trade" rules. According to this group, called the G-20, and a number of other developing country groups:

The most substantial results must be achieved in the areas where the greatest distortions lie, in particular on trade-distorting subsidies in agriculture, that displace developing country products and threaten the livelihoods of hundreds of millions of poor farmers. ... Market access will be an important component of a successful Round, but market opening in the developing countries must take into account their social and economic realities. (G-20 2006, "Joint Statement")

Far from this being a call to protectionism, the high subsidies developed nations provide their producers has been a significant sore point for developing countries unable to match these trade-distorting tactics to protect their own agricultures. A subsequent meeting in 2007 of four big trade powers (Brazil and India, representing developing countries, and the United States and the European Union, representing developed ones) to hammer out a preparatory agreement again resulted in failure (Palmer and MacInnis 2007). Broadly speaking then, the rounds' persistent failure can be directly attributed to unresolved tensions between developed and developing countries over the role of agriculture.

We will now turn to our case studies. As we will see, far from a mere "deregulation" process, what we have is a clear neoregulation agenda that favors the private sector and (selective) trade liberalization. The promotion of agricultural biotechnology is also an important economic strategy in the United States and Canada, whereas neoregulation and its resistances are broader in nature in Mexico.

\section{The United States}

As is clear from its stance on WTO negotiations, the United States as a whole is food secure (see Graph 1). While only 2 percent of the economically active population in the country is engaged in agriculture, the country nonetheless exported $\$ 68.7$ billion in agricultural products, and imported only $\$ 64$ billion, making it a net exporter of agricultural products (U.S. Department of Agriculture [USDA] 2007). These statistics are for all agricultural products, including cotton, whereas the statistics for Canada are more specifically for agrifood products.

U.S. major agrifood exports are soybeans, maize, and wheat (see Graph 2). The United States has been food secure for many decades: as we discussed, its ability to produce surpluses underwrote the second 


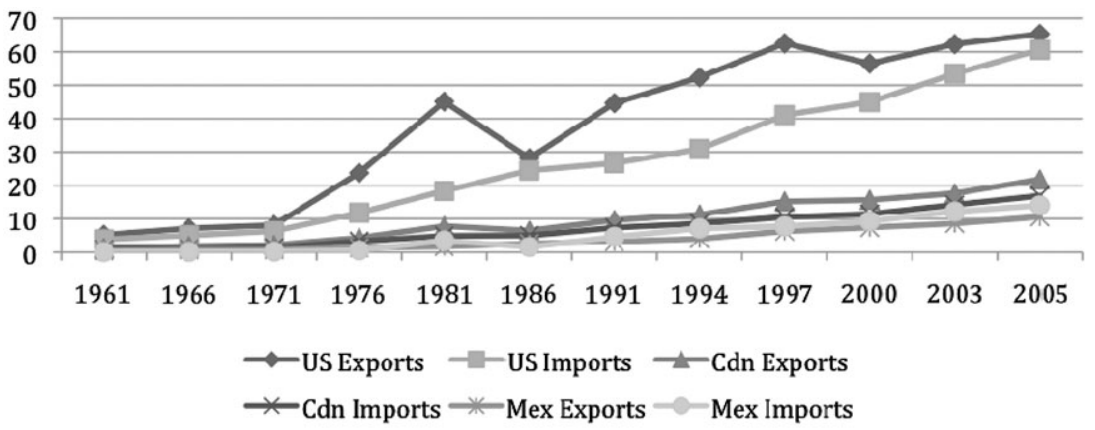

Graph 1. NAFTA Region: Agrifood Exports/Imports (US\$ billions, selected years)

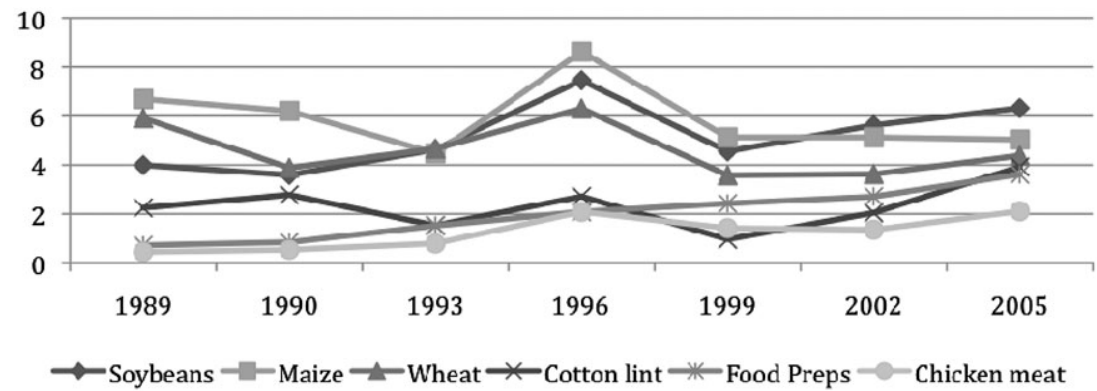

Graph 2. US Top-Five Agrifood Exports (US\$ billions, selected years)

food regime. The highly regulated national agriculture that the country created in this regime, however, clashes with tradeliberalization schemes, resulting in its being criticized for being disingenuous in promoting open markets for everyone else, while holding fast to its high level of (recategorized) agricultural subsidies. To date, it has been successful in maintaining this position, but the 2006 (and onward) failure in WTO negotiations suggests that there may be difficulties ahead.

Of the top four U.S. agrifood exports, all but wheat are primarily produced with genetically modified (GM) seeds. Soybeans displaced maize as the top export in the most recent years, while cotton lint regained its traditional fourth spot. Clearly, soybeans, maize, and wheat are central components of food diets in most of the world, including Mexico. In fact, maize and wheat are Mexico's third and fourth top imports, respectively, with cotton lint following closely in the sixth spot (see Graph 7). More than 90 percent of these imports to Mexico come 


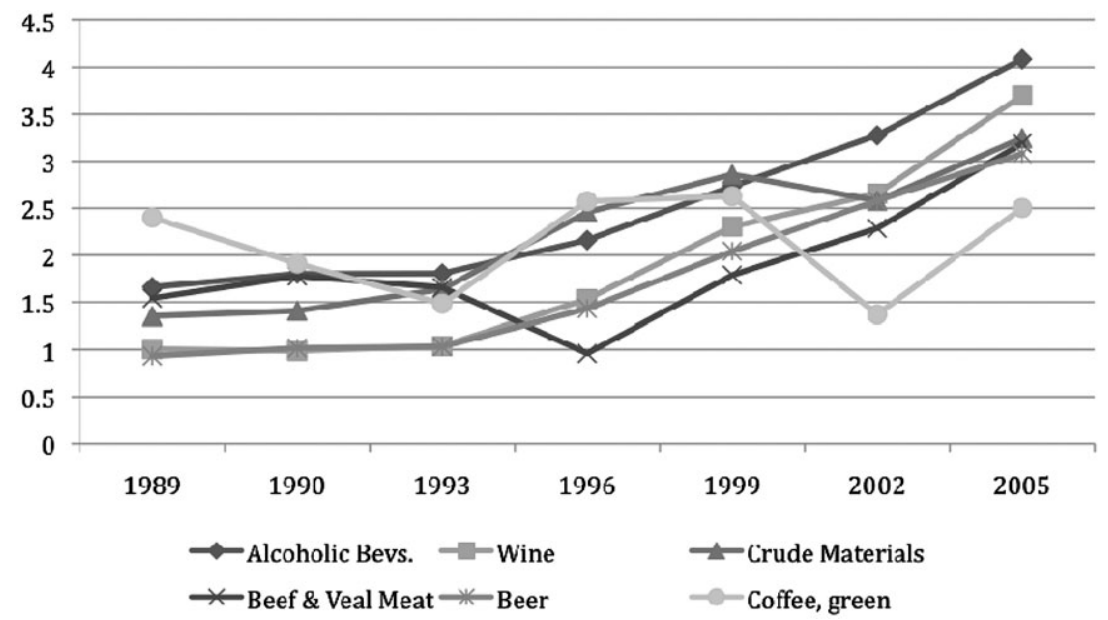

Graph 3. US Top-Six Agrifood Imports (US\$ billions, selected years)

from the United States. In contrast, U.S. agrifood imports can mostly be characterized as "luxury" items, or at least not basic food, with alcoholic distilled beverages in the top spot, followed by wine, crude materials (whose processing likely generates jobs), beef and veal boneless meat (imported mostly from Canada, perhaps), beer, and green coffee (again, for further processing) ${ }^{1}$

Further, the nature of agriculture is changing with the advent of agricultural biotechnologies. The United States is a driver in industrial agriculture's shift to GM varieties, both as the top adopter, globally, and in the development of the technology. In 2004, 75 percent of publicly traded biotechnology companies were based in the United States (15 percent were in Europe and 8 percent in Canada; see Graph 3). Agricultural biotechnology accounts for only a tiny contribution to this industry (3 percent) compared to health-related biotechnologies (82 percent) (ETC Group 2005a). However, as Pat Mooney, executive director of the ETC Group, notes, the "technology is poised to surpass trade as the defining feature of comparative advantage in the $21^{\text {st }}$ century"

\footnotetext{
${ }^{1}$ We derived all import-export crop rankings for the three NAFTA countries inductively from their positions in the latest year for which data were available: 2005. In most cases, the same rankings go back several years. For Mexico, we also followed the inverse procedure in Graph 8: we derived the top export rankings as of 1965 to get an idea of how traditional exports were displaced by or survived the neoliberal reforms. Only coffee and tomatoes remained in the top export categories, with coffee-a typically small-peasant crop-at a very diminished place and with great volatility after world-supply control collapsed in 1989 (Jaffee 2007). Displaced Mexican export commodities include cotton lint, boneless beef and veal meat, and raw sugar, with the first two now among its top imports (Graph 7).
} 
(ETC Group 2005b). The United States is clearly determined to capture this comparative advantage and make biotechnology an American industry. This impetus features strongly in its neoregulatory agenda, which favors the private sector, specifically through the pursuit of strong intellectual property rights (IPRs).

The United States strongly supports not only national IPRs but also a globally homogenous system of IPR protection. The country was instrumental in the establishment of global IPR protection through the Trade Related Aspects of Intellectual Property Rights Agreement of the WTO, and continues to protect the industry through lobbying against labelling GM products. Nationally, agricultural neoregulation for IPR protection has led to patents on life, such as seeds, and is poised to consign traditional seed-saving practices to the history books. The inadequate regulation of agricultural biotechnologies is the hallmark of the country's proindustry stance toward the technology (Pechlaner and Otero 2008). It is overseen by the policy principles of "substantial equivalence" and "generally recognized as safe," and plagued by regulatory failures (e.g., contamination incidents) and criticisms in internal audits, such as that of the Office of the Inspector General (USDA, Office of the Inspector General 2005). Given that by 2005 the country's top two agricultural exports, soybeans and maize, were 93 percent and 52 percent GM respectively (with cotton at 79 percent and canola 82 percent) (Brookes and Barfoot 2006:6), the country is strongly motivated to globalize its regulatory perspective on the technology's safety as well as on IPRs. Consequently, the United States has challenged the European Union's reluctance to approve new GM varieties at the WTO.

The double push of strong IPR protection and regulatory laxity have had the desired impact on the industry's growth, but national resistance to this neoregulation of the technology does exist. While there is some pressure from environmental organizations, in the United States its most significant form to date has manifested in the legal forum, such as through court challenges from individual farmers (over patent infringement) and environmental and other nongovernmental organizations (over technology approvals and patent validity). ${ }^{2}$ A number of local governments with environmentally inclined populations have either banned or voiced objections to the technology (Roff 2008). In states such as California, such resistance is notable; however, it remains limited in the larger context. There appears to be very little resistance from a popular front, unlike in Mexico.

\footnotetext{
${ }^{2}$ For more on regulation and resistance to agricultural biotechnology in the United States and Canada, see Pechlaner 2007.
} 


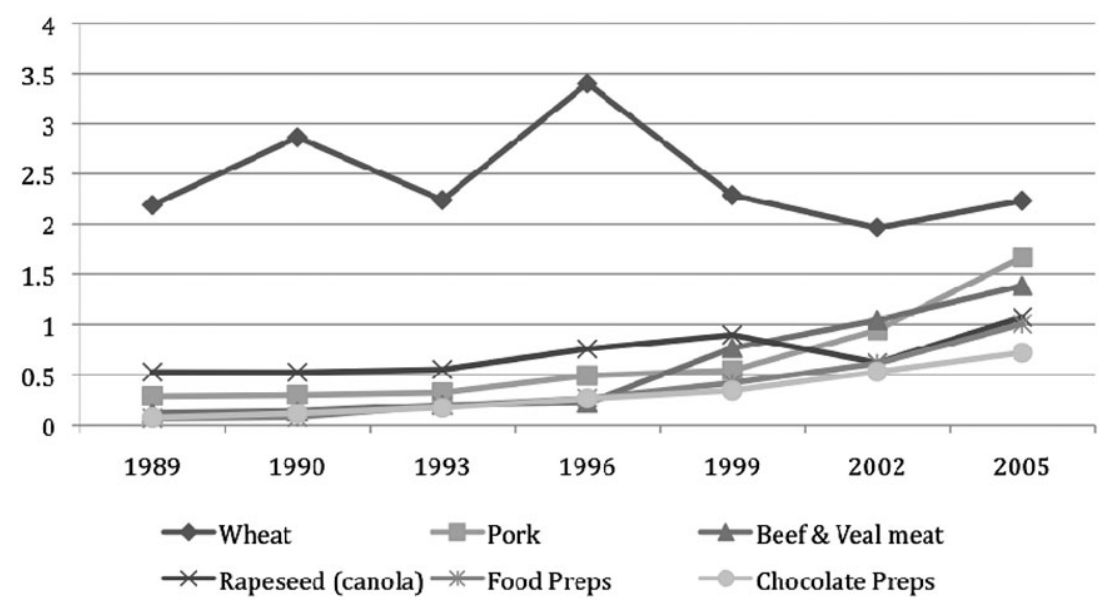

Graph 4. Canadian Top-Six Agrifood Exports (US\$ billions, selected years)

\section{Canada}

As in the United States, Canada's agricultural sector also constitutes only approximately 2 percent of the economically active population. Nonetheless, it enjoys a similar success in agricultural production. In 2006, Canada's imports and exports in agrifood both rose 6 percent from the year before. Canada exported $\$ 27.86$ billion in agrifood products, whereas it imported only $\$ 22.42$ billion for that same year (Agriculture and Agri-food Canada 2007). In fact, Canada is the world's third largest agricultural exporter ("Q\&A-WTO Meeting" 2005), after the United States and the European Union. Canada is a major exporter of wheat, pork, and boneless beef (see Graph 4). Of the top six Canadian agrifood exports, it is noteworthy that three of them are processed goods: boneless beef meat and food and chocolate preparations. Similarly, most of the next top Canadian exports involve processing: frozen potatoes ( 7 th), bread (9th), rapeseed oil (10th), sugar confectionaries (11th), and distilled alcoholic beverages (12th) (see the Statistical Appendix for the source for these data, FAOSTAT).

Agricultural trade, and trade in general, is extremely important to the country. No doubt related to this importance, Canada appears to fully embrace the free-trade ideology. As Peter Urmetzer argues, for example, Canada "has learned from past experience that the United States can quickly turn protectionist" and therefore it resorts to measures such as NAFTA and the WTO in the hopes of not being subjected to that country's "arbitrarily closing its borders" (Urmetzer 2003:131). At the 


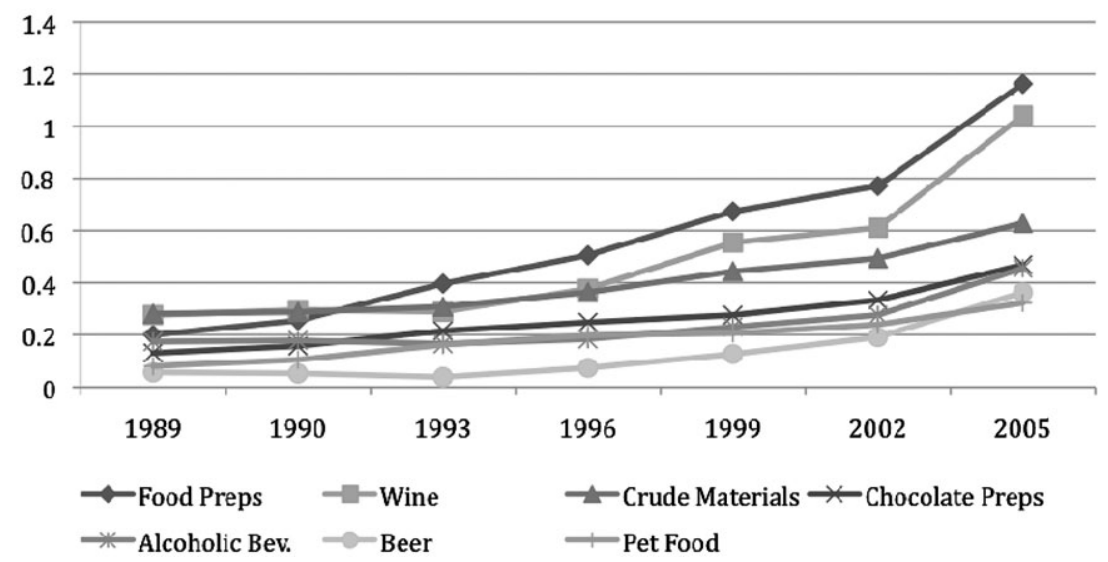

Graph 5. Canadian Top-Seven Agrifood Imports (US\$ billions, selected years)

same time, with respect to its own agrifood imports, Canada enjoys a similarly privileged position to the United States. Top agrifood imports for Canada are food preparations, wine, crude materials, chocolate preparations, alcoholic beverages, beer, and pet food (see Graph 5). Once again, the balance is on luxury items over basic foods.

While Canada's food security and low percentage of agricultural labor force keeps it from occupying the same vulnerable position as many developing countries, it does not have the political and economic clout of the United States or the European Union. Canada, therefore, is unable to engage in the same kind of highly subsidized farming as these two giants. For example, Canada's aggregate measure of support is only $\$ 3.7$ billion, as compared to $\$ 19.1$ billion for the United States, and $\$ 79$ billion for the European Union (all in U.S. dollars) ("Q\&A-WTO Meeting" 2005). In proportion to gross domestic product (GDP) and population, however, this makes Canada more-not less-protectionist than the United States. Yet in proportion to agricultural production, Canada's level of subsidies is lower than that of the United States. According to Canada's then federal minister of international trade, Jim Peterson, the Doha round of the WTO was held out to be the "only opportunity we have to rein in the obscene level of agricultural subsidies in the EU, the United States and Japan" (cited in "Q\&A-WTO Meeting" 2005).

Not to overstate the case, Canada does engage in some protectionist practices, such as single-desk marketing and supply management. The single-desk marketing system of the Canadian Wheat Board (CWB) is a cooperative marketing system whereby wheat and barley growers in 
western Canada market their product together, and therefore increase their ability to compete with transnational grain companies. The system has faced attack in WTO negotiations, despite CWB arguments that such marketing is not trade distorting (Canadian Wheat Board [CWB] n.d.). Supply management exists in Canada for products such as dairy, eggs, and poultry, which are controlled for domestic consumption. It has three tenets: production management (e.g., through quotas), import controls, and prices set to the cost of production. This system protects farmers by providing them with a stable income, and prevents the economic crises that can besiege farm sectors exposed to global-price fluctuations. Not surprisingly, it is under attack as counter to free-trade objectives. In some ways, then, Canada occupies a middle position, sometimes benefiting from trade-liberalization structures and sometimes buffeted by the same dumping practices that affect less developed countries. Where the country has protections for farmers, it faces significant political pressure to liberalize.

As in the United States, biotechnology features significantly in the Canadian government's economic development plans. While Canada has nowhere near the economic stake in the technology the United States does-compare $\$ 44.8$ billion in the United States with Canada's \$625 million, in Canadian dollars, in 2002 (Munn-Venn and Mitchell 2005:4, with data from the National Science Foundation)—it is still reasonably vested in capturing the comparative advantage of investment in the new industry. As in the United States, a large percentage of Canada's key export crops are GM (in 2005, 60 percent of soybeans, 65 percent of maize, and 95 percent of canola [Brookes and Barfoot 2006:6]). While soybeans are exported directly, occupying the 12th spot in Canadian agrifood exports, most maize and canola (or rapeseed) is used for further processing into pig feed and rapeseed oil, respectively. Pig feed and rapeseed oil take the 2nd and 4th spots in Canada's agrifood exports.

Consequently, neoregulation in Canada is similarly evident in regulations that favor private industry through weak regulatory oversight and strong IPR protection. While the country's IPR protection has historically been weaker than its southern neighbor's, this is changing: for example, while patents on life are banned in Canada, recent court decisions $^{3}$ have supported them in practice, if not in name. Furthermore, while overseen by different agencies, regulatory oversight of GM technology in Canada is itself "substantially equivalent" to that in the United States in many significant ways.

\footnotetext{
${ }^{3}$ E.g., Monsanto Canada Inc. v. Schmeiser (2004) [2004] 1 S.C.R. 902, 2004 SCC 34.
} 
Resistance to the neoregulation of biotechnology in Canada has manifested in some of the same legal challenges evident in the United States, and a fair amount of popular support has flourished around these legal challenges. Nonetheless, this resistance is fairly constrained and does not include widespread support outside of those concerned with the "issues" (e.g., agriculture, the environment, corporate concentration). A further form of resistance, also present in the United States, is practiced by concerned consumers who purchase organic foods overseen by private standards. The rise in private standards has provided alternatives (for rich consumers) to the products of a neoregulated agriculture (Busch and Bain 2004; Friedmann 2005). Of course, this pricier alternative is unavailable to many citizens in developed countries, and the vast majority of citizens in developing ones.

\section{Mexico}

Since 1979, Mexico has predominantly carried some degree of agricultural trade deficit, although the gap increasingly widened between the mid-1990s to 2005. In 2006, the country imported $\$ 15.98$ billion and exported $\$ 13.43$ billion (FAOSTAT, retrieved July 23, 2009). Mexico's agricultural sector has not been industrialized to the extent of the other two NAFTA countries. For example, in 1999 Mexico had only one tractor for every 158 hectares of cropland, in contrast to 37 hectares in the United States and 64 hectares in Canada (calculated from Earthtrends 2003). Furthermore, while in Canada and the United States farmers make up less than 2 percent of the economically active population, in Mexico they are almost 20 percent of the labor force. Despite the fact that agricultural productivity in Mexico is now considerably lower than that of its northern neighbors, its agriculture was the country's main producer of foreign exchange revenues until the mid-1960s. After that, the proindustrialization and antiagricultural policies that had prevailed since the 1940s began to take a steep toll: both peasant and capitalist agricultures entered into a crisis that had not left the country by the turn of the twenty-first century (Bartra 2004; Otero 1999).

Mexico's neoregulation consequently follows a different path than that of Canada and the United States, emphasizing rural transformation for trade liberalization. Mexico's 1992 agrarian reform legislation, which revised laws emanating from the revolution of 1910-1920, was geared to launch about half of agricultural lands into the market: it officially declared the end of the state's obligation to redistribute land to the peasantry and indigenous peoples; it allowed the privatization of formerly inalienable land in ejidos and agrarian communities; and it 
promoted the association between private capitalists and ejidatarios (title holders of ejido land). ${ }^{4}$

The other, unspoken goal of agrarian reform was to court foreign investment by "liberating" large contingents of workers from agriculture to sustain the cheap wages in industry and services (Bartra 2004). According to Bartra, Mexican officials deliberately wanted to empty the countryside of surplus labor power, and to bring the approximately 26 percent of economically active people in agriculture in the early 1990s_contributing a mere 7 percent of the gross national productcloser in line with its northern neighbors. This process was initiated through the radical elimination of most government supports for peasant production, including the virtual elimination of subsidized loans, the dismantling of a number of government-run agricultural marketing agencies, and the elimination of the government-run seed company (Cornelius and Myhre 1998; Otero 1999). This campaign has significantly reduced the agricultural population since the mid-1990s. The proportion of GDP attributable to agriculture and to those employed in the sector have similarly declined from pre- to post-NAFTA times. Agriculture's GDP contribution declined from about 16 percent in 1961 to 7 percent in 1993, just before NAFTA (Alcaraz and García Verdú 2006:9). Since then, it has further declined to a mere 3.2 percent in 2007 (Instituto Nacional de Estadística [INEGI] 2008). An official 2004 U.S. government report calls this decline "de-agriculturalization," whereby agricultural GDP represents only "a proportion to which developed countries' respective sectors did not descend until their per capita GDP had reached at least four times that of Mexico" (Condesa Consulting Group 2004:3). Similarly, the agricultural workforce declined from about 26 percent in the mid-1980s to below 14 percent by 2009 (INEGI 2009).

While certainly not to the extent evident in Canada and the United States, agricultural biotechnologies also play a role in the industrialization of Mexico's agricultural sector. Regulation of these new technologies in the country has been somewhat contradictory, straddling a European precautionary approach and a North American development drive. The Law of Biosecurity of Genetically Modified Organisms (LBOGM for its Spanish acronym) was enacted in 2005 to impose order over the heretofore haphazard process of GMO approvals. Maize, for example, is a highly important crop in Mexico, and Mexico's early precautionary approach toward its release was followed by a more liberal

\footnotetext{
${ }^{4}$ Both ejido and agrarian communities, in addition to private property, were land-tenure forms emanating from the agrarian reform process of 1917-1992 (Cornelius and Myhre 1998; Otero 1999).
} 
approach in 2002, with nine approvals granted by 2005 (Comisión Federal para la Protección [COFEPRIS] 2005). The LBOGM subsequently singled out this crop for special treatment. We discuss the role of maize (or corn) in trade and food vulnerability in more detail presently.

Resistance to neoliberal reform has been much more widespread in Mexico than in both Canada and the United States given the breadth and extent of its impact. The struggle includes wider demands for political democratization and the defense of the oil and power industries, which the neoliberal government had tried to privatize. A critical juncture was reached in the 2006 presidential elections, which were widely regarded as tainted, and in which the official winner from the right-of-center Party of National Action, Felipe Calderón, won by a margin of a mere 0.5 percent over Andrés Manuel López Obrador, from the left-of-center Party of the Democratic Revolution. By official count, neither candidate reached 37 percent of the vote. This juncture precipitated a massive social movement around López Obrador, who formulated a popular-democratic and nationalist agenda to defend national resources.

One of the critical sectors to be defended and indeed recovered by the popular movement is agriculture. The key movement slogan in this regard is sin maiz no hay pais ("without corn there is no country"). Since 1995, Mexico's countryside has lost over three million people who have migrated to cities and to the United States looking for a better life. While xenophobic and racist U.S. politicians are pushing for building a wall along the U.S.-Mexico border, they are clearly at odds with businesses that require the cheap labor offered by migrants (Hellman 2008). By supporting agriculture, however, Mexicans would no longer have to seek refuge in international migration. Thus, the principles proposed by the peasant movement to defend agriculture include the following: ${ }^{5}$ revalorizing agriculture's role; food sovereignty and the right to food; the rights to development and a dignified life for the rural population; the right of agrarian communities to land, territory, and natural resources; a productive strategy to combat rural poverty (including its governance); and acknowledgment of indigenous rights to autonomy and the principle of gender equality.

The starting point to advance toward implementing these principles is the renegotiation of NAFTA's Agricultural Chapter. Other immediate

\footnotetext{
${ }^{5}$ These proposals were presented at the National Democratic Convention in March 2007 (attended by one of us) by the following peasant organizations: Mexican Alliance for the Peoples' Self-Determination, or AMAP (all acronyms are from Spanish names); National Council of Peasant Organizations, CONOC (which in turn includes AMUCSS, ANEC, CEPCO, CNOC, FCDCh, Red Mocaf, Unofoc); Plan de Ayala National Coordination Ayala, CNPA; and El Barzón-ANPAP (National Alliance of Agricultural and Fisheries Producers).
} 
measures proposed include an emergency program to promote maize production, to combat privilege and monopoly in the agrifood sector, and to introduce a moratorium on transgenic corn, and three legislative measures: (1) the constitutional right to food, (2) a law on planning for food and nutritional sovereignty and security, and (3) a law to establish a permanent mechanism to manage imports and exports of corn and beans (and their derivatives). Clearly, the majority of these demands are at odds with the chief tenets of the neoliberal food regime.

The food-price hikes that started in late 2006 helped spur the peasant movement. On January 31, 2008, there was a massive demonstration in Mexico City of over 200,000 people (attended by one of us), in protest against NAFTA's full opening for all agricultural products. This protest had representatives from across the spectrum of peasant organizations, including the corporatist organizations of the formerly ruling Institutional Revolutionary Party. Workers' unions also participated in solidarity: the Mexican Electricity Workers Union, the independent National Workers' Union, and the dissident faction of the teachers' union, the National Education Workers' Coordinator (Hernández Navarro 2008). Some of the slogans branded at the protest said: "We want to be survivors, not losers in the neoliberal alchemy," and "NAFTA is great, yes, for the damn gringos" ("El TLCAN es muy bueno, pero para los pinches gringos”) (Hernández Navarro 2008). By mid-2009, the top 10 items with the highest price inflation in Mexico continued to be food products (Martinez 2009). We will discuss the food-price crisis and resistance to it further in the following section.

\section{The New International Division of Labor in Agrifood Production}

The contrast between the predominantly luxury imports of Canada and the United States with those of Mexico is notable: there is no doubt that Mexico is far more food vulnerable than the other two. Consequently, of the three NAFTA countries, only Mexico has seen food prices rise significantly during the global food crisis, starting in late 2006. Canada has actually experienced a 0.6 percent food deflation, likely caused by the appreciation of its currency by about 30 percent since 2002. In addition, "Canada's prices may be kept low because the country is producing much of its own food-possibly too much," said Bank of Nova Scotia senior economist Adrianne Warren (Scoffield and Strauss 2008:B1, B6). Due to reverse trends in its currency, which has been devalued significantly against other major currencies, price inflation in the United States was 4 percent in 2007 (Scoffield and Strauss 2008:B1). For the most part, however, this country is also substantially self-sufficient. Consequently, we focus on how Mexico has fared in the NAFTA-defined division of labor. 
While Mexico unilaterally opened its borders for most products in the late 1980s in preparation for NAFTA, this agreement contained some selective protection and phase-out periods for various crops. Corn, beans, sugar, and milk were given the longest phase-out period of protection of 14 years, which ended in 2008. By 2003, most agricultural products became liberalized, contributing to the already noted peasant protest movement (Bartra and Otero 2005; Sánchez Albarrán 2007). Even the London-based conservative newsweekly The Economist ("Mexico's Farmers" 2002), an enthusiastic supporter of free-market policies, and BusinessWeek's correspondent in Mexico City (Smith 2002) expressed their dismay over the Mexican government's meager support for its agricultural sector. These articles highlighted the international context of widespread agricultural subsidies throughout the advanced capitalist countries. In the NAFTA countries, "[r] elative to the value of national agricultural production, budgetary expenditures on farm payments during 1999-2001 equaled 15 percent in the United States, 10 percent in Canada, and 7 percent in Mexico" (Zahniser, Young, and Wainio 2005:2).

Agricultural trade liberalization in Mexico has caused a big shift to high-value fruit and vegetable production for export over that of lowervalue food grains for the domestic market, imports for which U.S. farmers receive heavy subsidies. As a result of such neoregulation, by 2003, Mexico had become dependent on the United States for the importation of some of its most critical foodstuffs, including maize and meat, two of the leading agricultural imports (see Graph 2). Significant amounts of corn were first imported from the United States in 1989, a tendency that continued to grow until 23 percent of Mexico's corn supply was imported by 2007. Once completely liberalized, corn imports grew by 19 times in January 2007 over the same month of the previous year. It should be clarified that Mexico imports yellow corn, used to produce animal feed, high-fructose corn syrup, or ethanol, while it continues to be self-sufficient in white corn for food production. But while white and yellow corn should properly be considered two different products, the reality is that the usually lower import prices of yellow corn have also caused prices for white corn to fall for producers.

Trade liberalization renders Mexico highly vulnerable to price fluctuations instigated in other countries. A dramatic example of this is the corn crisis triggered in 2006, when then U.S. president George Bush introduced a subsidy to produce corn-based ethanol in an effort to reduce his country's dependency on Middle Eastern oil. Whereas ethanol policy may well benefit U.S. and Canadian farmers, tortilla 


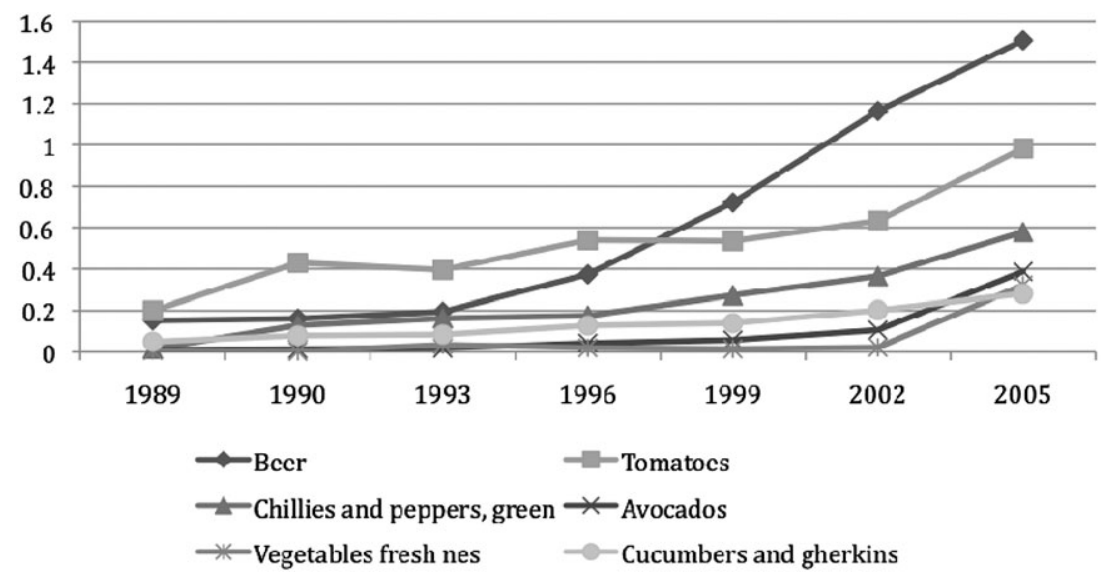

Graph 6. Mexico: Top-Six Agrifood Exports (US\$ billions, selected years)

prices in Mexico suffered a 60 percent increase in early 2007 due to increased dependency on maize imports (Roig-Franzia 2007). Price increases were also seen in wheat and its derivative products (e.g., bread, pasta), as many wheat farmers abandoned this crop in favor of the higher corn prices. By 2008, subsidies and bad weather in several grainproducing countries produced the highest food prices in decades. Reports in the news contained warnings of popular uprisings in about 40 nations around the world (e.g., Amenaza alza 2008; Poy Solano 2008).

Our review of Mexico's agricultural trade data from FAOSTAT confirms the conclusions of other studies of its food dependency and vulnerability: Its trade balance in agricultural production has been in deficit since before the start of NAFTA, but it has increased considerably since 1994 (de Ita 2007; González Chávez and Macías Macías 2007). In particular, we agree with the definition of "food vulnerability" given by Humberto González Chávez and Alejandro Macías Macías as "the situation that characterizes countries, social sectors, groups and individuals who are exposed or are susceptible to suffer from hunger, malnutrition or illness from not having physical, economic, and sustainable access to sufficient, nutritious and culturally-acceptable food, or for eating unsafe or contaminated products" (2007:48). While this definition builds on the main elements of the Food and Agriculture Organization's (FAO's) "food security," the concept we propose gives a more precise definition of food vulnerability. NAFTA and neoliberalism have turned Mexico into a food-import-dependent nation specifically with respect to the composition of imports and exports (see Graphs 6 and 7). By 2005, rice imports 


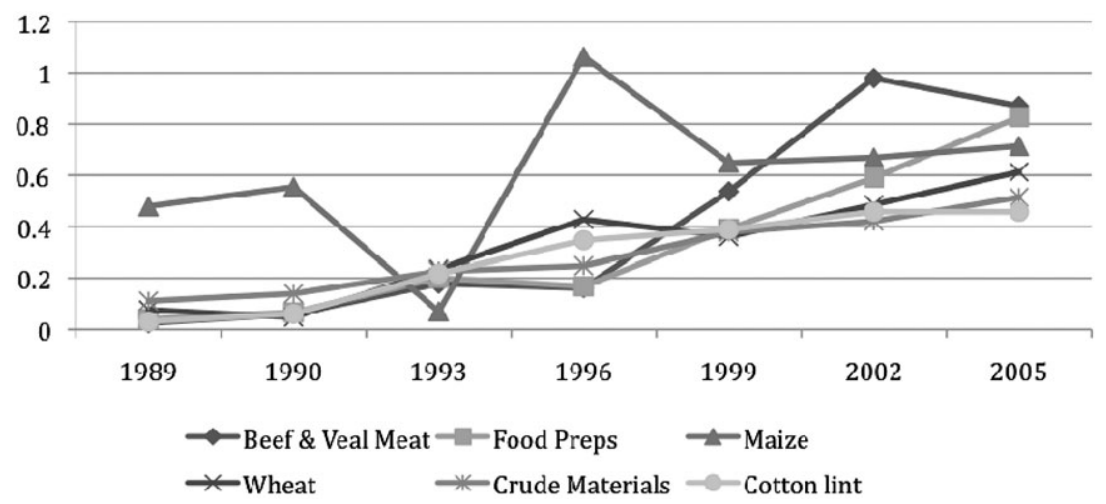

Graph 7. Mexican Top-Six Agrifood Imports (US\$ billions, selected years)

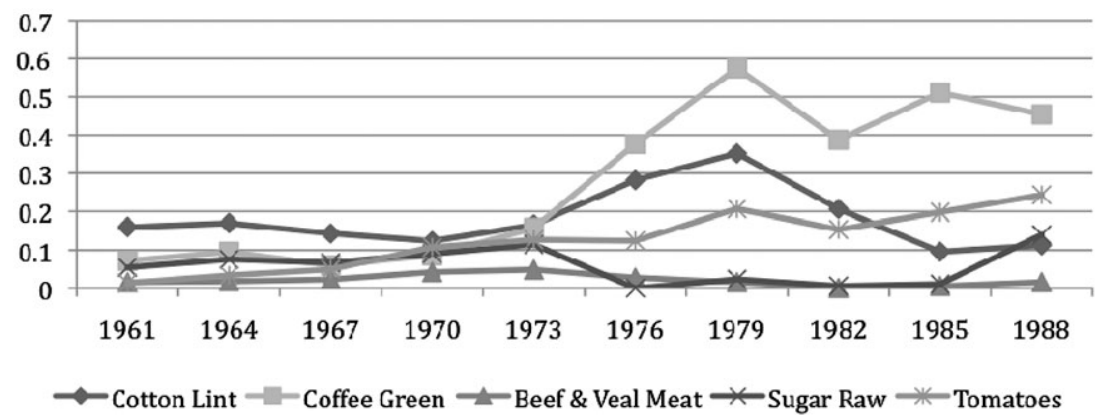

Graph 8. Mexico: Early Top-Five Agrifood Exports (US\$ billions, selected years)

made up 72 percent of domestic consumption, while wheat imports were 59 percent, maize 23 percent, and beans 9 percent (González Chávez and Macías Macías 2007).

Furthermore, Mexico's agricultural trade deficit with the United States is unreciprocated. Overall, since NAFTA has been in place, 84 percent of Mexican exports were destined for the United States, with a maximum of 89 percent in 2005 (González Chávez and Macías Macías 2007:58). The greatest grain imports to Mexico are: soybeans, maize, wheat, barley, rice, and sorghum. Conversely, the main Mexican exports are: vegetables (most notably, tomatoes, followed by green chilies and peppers), which have grown remarkably since the start of NAFTA; barley beer; and fruit (for example, avocados, lemons and limes, and grapes). While Mexican exports have indeed grown considerably, the main food suppliers of the United States continues to be the European Union, first, 
and Canada, second. Conversely, two main destinations of U.S. exports are Canada and Mexico, followed by Japan and the European Union (data from FAOSTAT, various dates, countries, and commodities). In short, Mexico's growing dependence on its northern neighbor is not reciprocal.

We might expect that Mexican producers to benefit massively from the increased agricultural exports. Only 20,000 of 7 million agricultural producers are the most dynamic, however. While there are 32,000 firms in the food industry, only 1,692 engage in exports, and only 300 firms account for 80 percent of all exports (González Chávez and Macías Macías 2007:58). Another possible beneficiary of Mexico's increased imports of cheaper food are consumers, but as we suggested, consumer food prices have actually doubled from 1993 to 2007 (e.g., up 733 percent for tortillas and 736 percent for white bread) in relation to general inflation (up 357 percent) since NAFTA's implementation. The minimum wage has deteriorated by 21 percent in real terms during the same period (González Chávez and Macías Macías 2007:67-68). Therefore, unlike in Canada, Mexican consumers have not benefited from trade liberalization.

Lastly, while Mexico's employed labor force increased by 9.8 percent between 1998 and 2007, it decreased in agriculture by 23.97 percent, from 7.5 million people to only 5.7 million (González Chávez and Macías Macías 2007:68). Other sectors of the Mexican economy have not produced the expected employment opportunities to absorb this surplus labor, as new manufacturing and service investments are marked by capital-intensive technologies required for global competition. Consequently, Mexico has become the main contributor to international labor migration in the world: between 2000 and 2005, more than two million people left the country, mostly to the United States (Corona and Tuirán 2006). ${ }^{6}$ The outward-migration phenomenon for twenty-first century Mexico has several consequences: for example, on the one hand, dollar remittances sent by migrants have become the second largest infusion of foreign currency into the economy after oil revenues (23 billion in 2006-see Graph 9), which began to flatten in 2007; on the other hand, Mexico has also lost its "labor sovereignty," defined as a nation's ability to offer gainful employment to a majority of its workforce (Bartra 2004). These rural unemployment trends have resulted in a worsening of inequality, measured by the Gini coefficient.

\footnotetext{
${ }^{6}$ Estimates by the Consejo Nacional de Población are even higher for this period at 2.8 million. See www.conapo.gob.mx. For further scholarship on the issue of agrarian displacement, see Araghi 2000.
} 


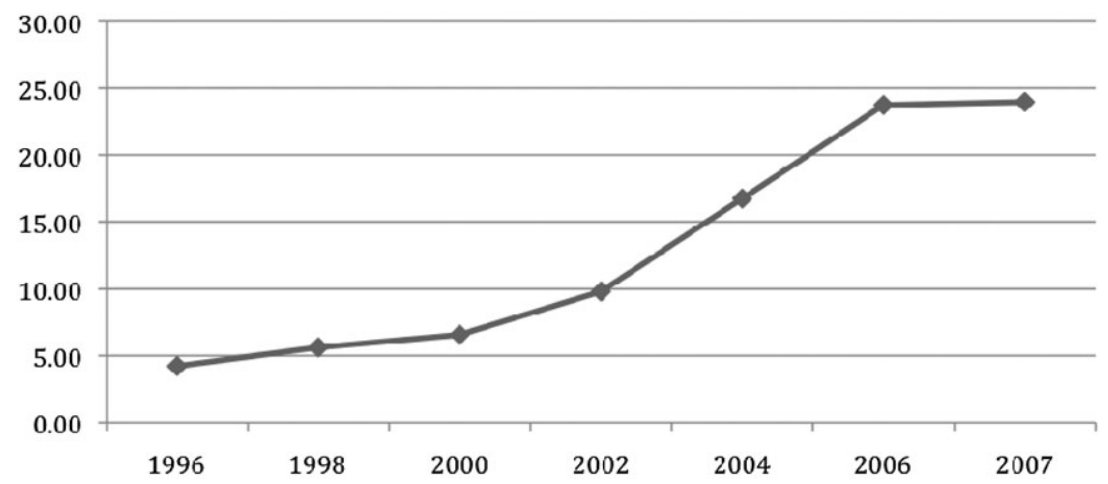

Graph 9. Mexico: Migrant's Remittances (US\$ billions)

In sum, the invasion of U.S. grain has led to the bankruptcy of a huge number of Mexican peasants, while the increase in vegetables and fruit exports from Mexico has not been enough to generate employment for peasants that became redundant. Unfortunately, Mexico's bid to use these "liberated" workers to attract foreign direct investment showed its failure in the 2001 U.S. slowdown, when Mexico lost 600,000 jobs during the first six months of the year as dozens of maquiladoras fled to even cheaper labor heavens, including China. This pattern repeated itself, only much more dramatically, with the deeper U.S. recession of 200810. In short, the only ones who have benefited from the export bonanza have been the more capitalized agricultural entrepreneurs, and U.S. firms and consumers. Agricultural liberalization, then, has brought the draining of Mexico's countryside and provoked the greatest rural population exodus that the country has experienced in its history. As a result, far from having achieved increasing living standards for Mexicans, NAFTA has actually increased the country's food vulnerability and dependency, a point not lost on its detractors. It is this very confluence of negative impacts that sparked the widespread peasant resistance movement, and may yet influence the future direction of the neoliberal food regime.

\section{Conclusion}

Given the limited nature of our case studies, our contribution to strengthening the FR perspective's ability to hypothesize (rather than historically map) is necessarily modest and mainly suggestive of areas for future research. At the very least, we have provided an empirical contribution to unfolding FR dynamics that have garnered much theoretical 
attention, and offered a partial response to Buttel's pertinent contention that the sociology of agriculture needs to simultaneously address agrarian change in both the North and the South. Qualifiers aside, our empirical results certainly support a FR perspective that incorporates food vulnerability and resistance in a way that could be abstracted and generalized: these variables can be posited as the antithesis of the dynamic we see as the driving forces of the neoliberal food regime, neoregulation and corporate-driven biotechnology.

A background assumption is that the adoption of neoliberal regulatory prescriptions requires national "buy-in" on a broad basis, which will differ even between countries of relatively equal resources. While we saw evidence of this national buy-in from all three of our case-study nations, Mexico demonstrated a continued commitment to the neoliberal path despite its negative impacts: "liberating" large masses of peasants into the reserve army of the unemployed and keeping wages down was clearly a greater policy goal than preserving food and labor sovereignty. While neoliberalism in Mexico has clearly been hegemonic among its technocracy since the mid-1980s (Babb 2001; Centeno 1994), this buy-in is not necessarily replicated in other developing countries like Brazil or India. Therefore, an important area for further research relates to how countries buy in to neoliberalism, the extent to which it is popularly accepted, and how this affects their integration into the neoliberal food regime.

Because Mexico is a less than democratic nation, the fact that its ruling class and government technocracy bought into neoregulation had little to do with how broader sectors of the nation perceived it. While the trends are dire, the massive protests by peasant groups and their supporters are sufficient to question whether the neoliberal food regime will be successfully implemented in Mexico. We are not claiming that neoliberalism lacks detractors or produces no negative impacts in Canada and the United States - the struggle over supply management in Canada is a case in point to the contrary-but it is the least-developed country that has the greatest negative repercussions from such restructuring, and consequently, the most resistance from the ground.

Our contention that resistance such as we see in Mexico could derail neoliberalism's implementation has been supported by others' work on bottom-up resistance, such as through peasant movements like Via Campesina (Desmarais 2007, 2008; McMichael 2004b; Patel 2006). We suggest, however, that nation-specific investigation of how different countries incorporate or contest neoliberalism-at least with respect to agriculture-will be key for determining the shape of the neoliberal food regime in its present transition. Even if the pace of globalization slows down because of the 2008 U.S. recession, it is an open question 
whether its core neoliberal ideology will be modified in a significant way. It is clear that transnational mobilization may limit the activity of suprastate organizations like the WTO. Yet it is ultimately at the level of the nation-state that neoregulation takes hold. Our main methodological-and political-point, then, is that we must disaggregate the large abstractions and macro-structural focus of world-systems perspectives within food-regime analysis. Only thus can we fruitfully combine the sociology of agriculture and development sociology, so that nation-states and their interaction become key units of analysis-and of political change. Pedro Magaña Guerrero, a Mexican peasant whose organization is a member of Via Campesina, put it this way after praising militancy at the global level: "The consolidation of alternatives rests completely on what is happening at the local level, it depends on the development of organizations in their [peasants'] regions, in their countries" (quoted in Desmarais 2007:135). Looking within nation-states will thus allow for studying how and whether their internal sociopolitical dynamics may become independent factors that could alter dominant trends in the world economy from the bottom up.

\section{References}

Agriculture and Agri-food Canada. 2007. "Imports—Agri-Food for 2006." Retrieved June 19, 2007 (http://atn-riae.agr.ca/stats/4142_e.pdf).

Alcaraz, C. and García Verdú, R. 2006. "Cambios en la composición del empleo y evolución de la productividad del trabajo en el sector formal de la economía mexicana: 20002005." Banco de México. Working Papers, no. 2006-3. Mexico City, Mexico: Banco de México.

"Amenaza alza de alimentos estabilidad." 2008. Reforma, April 16. Retrieved April 16, 2008 (http://www.reforma.com/internacional/articulo/437/873059/).

Araghi, F. 2000. "The Great Global Enclosure of Our Times: Peasants and the Agrarian Question at the End of the Twentieth Century." Pp. 145-60 in Hungry for Profit: The Agribusiness Threat to Farmers, Food and the Environment, edited by F. Magdoff and J. Bellamy. New York: Monthly Review Press.

_. 2003. "Food Regimes and the Production of Value: Some Methodological Issues." Journal of Peasant Studies 30(2):41-70.

Babb, S. 2001. Managing Mexico: Economists from Nationalism to Neoliberalism. Princeton, NJ: Princeton University Press.

Barndt, D. 2004. "Fruits of Injustice: Women in the Post-NAFTA Food System." Pp. 37-51 in Otero 2004b.

- 2008. Tangled Routes: Women, Work, and Globalization on the Tomato Trail. 2nd ed. Lanham, MD: Rowman and Littlefield.

Bartra, A. 2004. "Rebellious Cornfields: Toward Food and Labour Self-sufficiency." Pp. 18-36 in Otero 2004b.

Bartra, A. and G. Otero. 2005. "Contesting NAFTA and Neoliberalism in Rural Mexico: The Rise of a Politically-Formed Peasantry?" Journal for Latino-Latin American Studies 1(Special Issue, Fall):64-190.

Brookes, G. and P. Barfoot. 2006. "GM Crops: The First Ten Years-Global SocioEconomic and Environmental Impacts." ISAAA Brief no. 36. Ithaca, NY: International Service for the Acquisition of Agri-Biotech Applications. 
Burbach, R. and P. Flynn. 1980. Agribusiness in the Americas. New York: Monthly Review Press.

Busch, L. and C. Bain. 2004. "New! Improved? The Transformation of the Global Agrifood System.” Rural Sociology 69(3):321-46.

Buttel, F. 2001. "Some Reflections on Late Twentieth Century Agrarian Political Economy." Sociologia Ruralis 41(2):165-81.

Canadian Wheat Board. N.d. "Backgrounder: WTO Issues for the CWB." Winnipeg, MB Canadian Wheat Board. Retrieved July 5, 2007 (http://www.cwb.ca/public/en/hot/ trade/issues/).

Centeno, M.Á. 1994. Democracy within Reason: Technocratic Revolution in Mexico. University Park, PA: Pennsylvania State University Press.

Clarkson, S. 2008. Does North America Exist? Governing the Continent after NAFTA and 9/11. Toronto, ON: University of Toronto Press.

Comisión Federal para la Protección contra los Riesgos Sanitarios (COFEPRIS). 2005. "Productos biotecnológicos para consumo humano que se han evaluado y aceptado para su comercialización en México.” COFEPRIS. Retrieved November 12, 2007 (http://www.cofepris.gob.mx/pyp/biotec/OMG.pdf).

Condesa Consulting Group. 2004. "Mexico-Agricultural Situation: Summary of Mexican Government Study on the Effects of NAFTA on Mexican Agriculture." GAIN Report no. MX4070, July 6. Washington, DC USDA Foreign Agricultural Service.

Constance, D., A. Bonanno, C. Cates, D.L. Argo, and M. Harris. 2003. "Resisting Integration in the Global Agro-Food System: Corporate Chickens and Community Controversy in Texas." Pp. 103-18 in Globalization, Localization and Sustainable Livelihoods, edited by R. Almasand and G. Lawrence. Aldershot, England: Ashgate.

Cornelius, W. and D. Myhre, eds. 1998. The Transformation of Rural Mexico: Reforming the Ejido Sector. La Jolla, CA: Center for U.S.-Mexican Studies, University of California, San Diego.

Corona, R. and R. Tuirán, 2006. "Magnitud aproximada de la migración mexicana a Estados Unidos.” Paper presented at Congreso Internacional de Migración: Alcances y límites de las políticas migratorias, Mexico City, Mexico, October 5.

De Ita, A. 2007. "Catorce años de TLCAN y la crisis de la tortilla." Special report for Programa de las Americas, November 11. Washington, DC: Center for International Policy.

Desmarais, A.A. 2007. La Via Campesina: Globalization and the Power of Peasants. Halifax, NS: Fernwood Press.

- 2008. "The Power of Peasants: Reflections on the Meanings of La Via Campesina." Journal of Rural Studies 24(2):138-49.

Earthtrends. 2003. "Country Profiles-Agriculture and Food." Earthtrends. Retrieved June 19, 2007 (http://earthtrends.wri.org).

ETC Group. 2005a. “Oligopoly, Inc. 2005: Concentration in Corporate Power.” ETC Group Communique, no. 91, December. Retrieved March 11, 2008 (http://www.etcgroup. org/en/archives.html).

- 2005b. "ETC Group Releases New Report on Corporate Power, Oligopoly, Inc. 2005." ETC Group news release. Retrieved February 11, 2006 (http://www.etcgroup. org/en/materials/publications.html?pub_id=42).

Fold, N. and B. Pritchard. 2005. Introduction. Pp. 1-22 in Cross-Continental Food Chains, edited by N. Fold and B. Pritchard. London, England: Routledge.

Food and Agriculture Organization (FAO). N.d. "FAO Statistical Yearbook: Country Profiles." Retrieved June 21, 2007 (http://www.fao.org/countryprofiles/index.asp? lang=en\&iso3=MEX\&subj=4).

Friedmann, H. 1992. "Distance and Durability: Shaky Foundations of the World Food Economy." Third World Quarterly 13(2):371-83. 57.

- 1995. "The International Political Economy of Food: A Global Crisis." International Journal of Health Services 25(3):511-38.

- 2000. "What on Earth Is the Modern World-System? Foodgetting and Territory in the Modern Era and Beyond." Journal of World-Systems Research 1(2):480-515. 
2005. "From Colonialism to Green Capitalism: Social Movements and Emergence of Food Regimes." Research in Rural Sociology and Development 11:227-64.

Friedmann, H. and P. McMichael. 1989. "Agriculture and the State System: The Rise and Decline of National Agricultures, 1870 to the Present." Sociologia Ruralis 29(2):93117.

G-20. 2006. Joint Statement G-20, the G-33, the ACP, the LDCs, the African Group, the SVEs, NAMA-11, Cotton-4 and CARICON. July 1. Retrieved March 3, 2008 (http://www. g-20.mre.gov.br/conteudo/statement_01072006.htm).

González Chávez, H. and A. Macías Macías. 2007. "Vulnerabilidad alimentaria y política agroalimentaria en México.” Desacatos: Revista de Antropología Social 25:47-78.

Harris, R.L. 2002. "Introduction: Globalization and Globalism in Latin America: Contending Perspectives." Latin American Perspectives 29(6):5-23.

Hay, C., M. Lister, and D. Marsh, eds. 2006. The State: Theories and Issues. New York: Palgrave McMillan.

Hellman, J.A. 2008. The World of Mexican Migrants: The Rock and the Hard Place. New York: New Press.

Hernández Navarro, L. 2008. "El campo mexicano, desprotegido ante el acuerdo commercial, advierten productores." La Jornada, February 1. Retrieved February 1, 2008 (http://www.jornada.unam.mx/2008/02/01/index.php?section=politica\&article $=$ $005 \mathrm{n} 1 \mathrm{pol}$ ).

Instituto Nacional de Estadística, Geografía e Informática (INEGI). 2008. "Producto interno bruto anual a precios constantes por sector de actividad económica." Retrieved November 26, 2008 (http://dgcnesyp.inegi.org.mx/cgi-win/bdiecoy.exe/ 785 ? $\mathrm{c}=12495$ ).

- 2009. "Indicadores oportunos de ocupación y empleo: Cifras preliminares durante mayo de 2009." Boleltin no. 175/09, June 24. Aguascalientes, Ags. Retrieved July 19, 2009 (http://www.inegi.org.mx/inegi/contenidos/espanol/prensa/comunicados/ ocupbol.asp).

Jaffee, D. 2007. Brewing Justice: Fair Trade Coffee, Sustainability and Survival. Berkeley, CA: University of California Press.

Le Heron, R. and M. Roche. 1995. “A 'Fresh’ Place in Food's Space.” Area 27(1):23-33.

Martinez, J.M. 2009. "Los 10 productos cuyo precio sube y sube.” CNNExpansion.com, June 9. Retrieved June 30, 2009 (http:/ / www.cnnexpansion.com/economia/2009/06/09/ los-10-productos-cuyo-precio-sube-y-sube).

Mascarenhas, M. and L. Busch. 2006. "Seeds of Change: Intellectual Property Rights, Genetically Modified Soybeans and Seed Saving in the United States." Sociologia Ruralis 46(2):122-38.

McBride, S. and J. Shields. 1997. Dismantling a Nation: The Transition to Corporate Rule in Canada. Halifax, NS: Fernwood.

McMichael, P. 1992. "Tensions between National and International Control of the World Food Order: Contours of a New Food Regime.” Sociological Perspectives 35(2):343-65. - 1996. "Globalization: Myths and Realities." Rural Sociology 61(1):25-55.

. 2004a. "Biotechnology and Food Security: Profiting on Insecurity." Pp. 137-53 in Global Tensions: Challenges and Opportunities in the World Economy," edited by L. Benería and S. Bisnaith. New York: Routledge.

- 2004b. "Global Development and the Corporate Food Regime." Symposium on New Directions in the Sociology of Global Development, XI World Congress of Rural Sociology, Trondheim. July 2004. Retrieved January 21, 2010 (http://www.corporateaccountability.org/eng/documents/2004/corporate_food_regime.pdf).

"Mexico's Farmers: Floundering in a Tariff-Free Landscape." 2002. Economist 365(8301): 31-32.

Moran, W., G. Blunden, M. Workman, and A. Bradly. 1996. "Family Farmers, Real Regulation, and the Experience of Food Regimes." Journal of Rural Studies 12(3):245-58.

Morton, A.D. 2003. "Structural Change and Neoliberalism in Mexico: 'Passive Revolution' in the Global Political Economy.” Third World Quarterly 24(4):631-53. 
Munn-Venn, T. and P. Mitchell. 2005. "Biotechnology in Canada: A Technology Platform for Growth." Report for the Conference Board of Canada. December 2005. Retrieved August 20, 2007 (http://www.agwest.sk.ca/biotech/documents/115-06Biotechnology\%20in\%20Canada.pdf).

Nagatada, T. 2006. "Global Flows of Fruit and Vegetables in the Third Food Regime." Journal of Rural Community Studies 102:25-41.

Nath, K. 2006. WTO Press Conference Audio Statement for June/July 2006 Modalities Meetings. July 24. Geneva, Switzerland: WTO. Retrieved July 3, 2007 (http://www.wto.org/english/ tratop_e/dda_e/modalities06_e.htm).

Novek, J. 2003. "Intensive Hog Farming in Manitoba: Transnational Treadmills and Local Conflicts." Canadian Review of Sociology and Anthropology 40(1):3-26.

Ó Riain, S. 2000. "States and Markets in an Era of Globalization." Annual Review of Sociology 26:187-213.

Otero, G., ed. 1996. Neoliberalism Revisited: Economic Restructuring and Mexico's Political Future. Boulder, CO: Westview Press.

- 1999. Farewell to the Peasantry? Political Class Formation in Rural Mexico. Boulder, CO: Westview Press.

- 2004a. "Global Economy, Local Politics: Indigenous Struggles, Citizenship and Democracy." Canadian Journal of Political Science 37(2):325-46.

-., ed. 2004b. Mexico in Transition: Neoliberal Globalism, the State and Civil Society. London, England: Zed Books; Halifax, NS: Fernwood Press.

- ed. 2008. Food for the Few: Neoliberal Globalism and Biotechnology in Latin America. Austin, TX: University of Texas Press.

Otero, G. and G. Pechlaner. 2008. "Latin American Agriculture and Biotechnology: Temperate Dietary Pattern Adoption and Unsustainability.” Pp. 31-60 in Otero 2008.

. 2009. "Is Biotechnology the Answer? The Evidence from NAFTA." NACLA Report on the Americas 42(3):27-31.

Palmer, D. and L. MacInnis. 2007. "G-4 Talks Collapse, Throw Trade Round into Doubt." Reuters, June 21. Retrieved March 3, 2007 (http://www.reuters.com/article/ topNews/idUSL2179513320070621).

Patel, R. 2006. "International Agrarian Restructuring and the Practical Ethics of Peasant Movement Solidarity." Journal of Asian and African Studies 41(1-2):71-93.

Pechlaner, G. 2007. Beyond the Science of Agricultural Biotechnology: Corporate Technology, Law and Local Control over Food Production. PhD dissertation, Simon Fraser University, Burnaby, BC.

Pechlaner, G. and G. Otero, 2008. "The Third Food Regime: Neoliberal Globalism and Agricultural Biotechnology in North America." Sociologia Ruralis 48(4):351-71.

Polanyi, K. 1944. The Great Transformation. New York: Rinehart.

Poy Solano, L. 2008. "Inminente explosión social mundial por escalada en precios de alimentos: UNESCO.” La Jornada, April 16. Retrieved April 16, 2008 (http://www. jornada.unam.mx/2008/04/16/index.php?section=sociedad\&article=045n1soc) .

Pritchard, B. 1998. "The Emergent Contours of the Third Food Regime: Evidence from the Australian Dairy and Wheat Sectors.” Economic Geography 74(1):64-74.

Pritchard, B. and D. Burch. 2003. Agrifood Globalization in Perspective: International Restructuring in the Processing Tomato Industry. Aldershot, England: Ashgate.

"Q\&A-WTO Meeting: Jim Peterson on Crippling Agricultural Subsidies and Canada's Trade Policy." 2005. Canadian Business. Retrieved July 5, 2007 (http://www. canadianbusiness.com/after_hours/opinions/article.jsp?content=20051230_155114_ 4640\&page $=2$ ).

Roff, R. 2008. Revolution from the Aisle? Anti-Biotechnology Activism and the Politics of Agrifood Restructuring. PhD dissertation, Simon Fraser University, Burnaby, BC.

Roig-Franzia, M. 2007. "A Culinary and Cultural Staple in Crisis: Mexico Grapples with Soaring Prices for Corn-and Tortillas.” Washington Post Foreign Services, January 27, p. A1. Retrieved June 28, 2007 (http://www.washingtonpost.com/wp-dyn/content/ article/2007/01/26/AR2007012601896_pf.html). 
Sánchez Albarrán, A. 2007. El campo no aguanta más. Mexico City, Mexico: M.A. Porrúa.

Sanderson, S.E. 1986. The Transformation of Mexican Agriculture: International Structrure and the Politics of Rural Change. Princeton, NJ: Princeton University Press.

Scoffield, H. and M. Strauss. 2008. "Against the Grain.” Toronto Globe and Mail, April 17, pp. B1, B6.

Smith, G. 2002. "Farmers Are Getting Plowed Under: With Tariffs Disappearing, U.S. Exports to Mexico May Soar." BusinessWeek, November 18, p. 53.

Stanford, L. 2004. "The Binational Integration of the US-Mexican Avocado Industries: Examining Responses to Economic Globalism.” Pp. 186-203 in Otero 2004b.

U.S. Department of Agriculture (USDA). 2007. "Outlook for U.S. Agricultural Trade." Washington, DC: USDA. Retrieved June 21, 2007 (http://usda.mannlib.cornell.edu/ usda/current/AES/AES-05-31-2007.pdf).

USDA, Economic Research Service. 2001. "WTO: Doha Development Agenda." USDA, ERS briefing. Retrieved June 30, 2007 (http://www.ers.usda.gov/Briefing/wto/ doha.htm).

USDA, Office of Inspector General, Southwest Region. 2005. "Audit Report: Animal and Plant Health Inspection Service Controls over Issuance of Genetically Engineered Organism Release Permits.” Audit 50601-Te. Washington, DC: USDA. Retrieved June 30, 2007 (http://nsrg.neu.edu/resources/regulatory_capacity/documents/ 5060108TE.pdf).

Urmetzer, P. 2003. From Free Trade to Forced Trade: Canada in the Global Economy. Toronto, ON: Penguin Books Canada.

2005. Globalization Unplugged. Toronto, ON: University of Toronto Press.

Valdéz Ugalde, F. 1996. "The Private Sector and Political Regime Change in Mexico.” Pp. 127-48 in Otero 1996.

Weiss, L. 1997. "Globalization and the Myth of the Powerless State." New Left Review 225:3-27.

Wells, M. 1997. "Legal Discourse and the Restructuring of Californian Agriculture: Class Relations at the Local Level." Pp. 235-55 in Globalising Food: Agrarian Questions and Global Restructuring, edited by D. Goodman and M. Watts. London, England: Routledge.

World Trade Organization (WTO). N.d.a. "Agriculture: Fairer Markets for Farmers." Retrieved June 30, 2007 (http://www.wto.org/english/thewto_e/whatis_e/tif_e/ agrm3_e.htm).

WTO. N.d.b. "Doha Development Agenda: Negotiations, Implementation and Development.” Retrieved June 30, 2007 (http://www.wto.org/english/tratop_e/dda_e/ negotiations_summary_e.htm).

Zahniser, S., E. Young, and J. Wainio. 2005. "Recent Agricultural Policy Reforms in North America.” April. Washington, DC: USDA, Economic Research Service. Retrieved June 15, 2007 (http://www.ers.usda.gov/publications/WRS0503/wrs0503.pdf).

\section{Statistical Appendix}

Graphs 1-8 were constructed with data from FAOSTAT, downloaded November 20-25, 2008. Trade (import and export) data are available at: http://faostat.fao.org/site/ 535/default.aspx\#ancor. Production data are available at: http://faostat.fao.org/ site/526/default.aspx. Graph 9 was constructed with data from Banco de México, downloaded on 26 November 2008, available at: http://www.banxico.org.mx/ SieInternet/consultarDirectorioInternetAction.do?accion=consultarCuadro\&idCuadro= $\mathrm{CE} 80 \&$ locale $=\mathrm{es}$. 